\title{
EFEKTIVITAS TEKNIK PENGANDAIAN DIRI DALAM PEMBELAJARAN MENULIS CERITA PENDEK
}

\author{
Suardi Zain, M. Nurzin R. Kasau, dan Suhartini \\ STKIP Muhammadiy ah Sidenreng Rappang \\ Jalan Poros Parepare No. 19 Lt. Salo Rappang, Kabupaten Sidenreng Rappang \\ email: suardi_zain@yahoo.com
}

DOI: $\underline{10.26858 / \text { retorika.v 10i2.4856 }}$

\begin{abstract}
The Effectiveness of Self Assignment Technique to the Ability of Writing Short Story. This study aims to describe the effectiveness of self-prescribing techniques on the ability to write short stories. This research is a quantitative research that try to apply self-prescribing technique in writing short stories. Data collection techniques used in this research are documentation and writing skill. The data analysis technique used is descriptive statistical techniques in the formt-tes. The results of data analys is in this study indicate that the self-efficacy technique is effective on the ability to write short stories in the seventh grade students of SMP.
\end{abstract}

\begin{abstract}
Abstrak: Efektivitas Teknik Pengandaian Diri terhadap Kemampuan Menulis Cerita Pendek Siswa. Penelitian ini bertujuan untuk mendeskripsikan efektivitas teknik pengandaian diri terhadap kemampuan menulis cerita pendek. Penelitian ini merupakan penelitian kuantitatif yang berusaha menerapkan teknik pengandaian diri dalam menulis cerpen. Teknik pengumpulan data yang digunakan dalam penelitian ini yaitu teknik dokumentasi dan tes kemampuan menulis. Adapun teknik analisis data yang digunakan yaitu teknik statistik inferensial dalam bentuk t-tes. Hasil analisis data dalam penelitian ini menunjukkan bahwa teknik pengandaian diri efektif terhadap kemampuan menulis cerita pendek pada siswa kelas VII SMP.
\end{abstract}

Kata kunci: menulis, teknik pengandaian diri, cerpen

Menulis sastra merupakan salah satu kompetensi yang harus dimiliki oleh siswa. Namun demikian, dalam menulis sastra, siswa sering mengalami kesulitan. Banyak faktor yang menyebabkan kesulitan tersebut, di antaranya ketidakbiasaan siswa menuangkan ide dalam bentuk tulisan serta ketidakmampuan siswa menyusun ide-idenya dalam bentuk sebuah karangan yang baik. Salah satu kompetensi yang harus dikuasai dalam pembelajaran sastra adalah menulis cerita pendek (cerpen). Cerita pendek (cerpen) adalah cerita berbentuk prosa yang relatif pendek. Cerita pendek mengisahkan sepenggal kehidupan manusia yang penuh pertikaian mengharukan atau menyenangkan, dan mengandung kesan yang tidak mudah untuk dilupakan (Laksana 2009: 61).

Berdasarkan pengamatan yang sudah dilakukan di SMP Negeri 2 Baranti Kabupaten
Sidenreng Rappang, sebagian besar peserta didik hanya menulis ketika mereka mendapatkan tugas dari guru. Sebaliknya, kurang dari satu pertiga siswa itu menulis buku harian, itupun ti-dak semua dari siswa menulis secara rutin setiap harinya dengan alasan siswa memiliki waktu yang terbatas untuk mengerjakan tugas-tugas mata pelajaran lain. Ataupun bila ada waktu luang, mereka lebih memaanfaatkan dengan bersantai, bermain, menonton televisi, pergi bersama teman atau keluarga.

Keterampilan menulis cerpen merupakan salah satu keterampilan berbahasa yang sangat penting bagi kehidupan manusia, yaitu sebagai alat komunikasi. Penulis menyampaikan informasi kepada pembacanya melalui simbol-simbol bahasa yang dapat dibaca, dipahami, dan dimengerti. Jadi menulis kreatif sastra adalah suatu proses yang digunakan seseorang dalam bentuk 
perasaan, kesan, imajinasi dan bahasa yang dikuasai seseorang dan pikiran seseorang dalam bentuk karangan baik puisi maupun prosa (Nugroho, 2009:4). Penulis menyampaikan informasi kepada pembacanya melalui simbolsimbol bahasa yang dapat dibaca, dipahami, dan dimengerti.

Menulis cerpen tentang kehidupan diri sendiri merupakan sebuah karangan. Karangan yang baik tentu saja harus memenuhi sebuah cerita untuk menjadi karangan yang bagus. Karangan yang bagus tentu saja mempunyai unsurunsur yang membangunnya. Menurut Haris (dalam Nurgiyantoro 2001:306) unsur-unsur karangan adalah content (isi, gagasan yang dikemukakan) dan mechanics (ejaan). Unsur-unsur tersebut dapat dijadikan bahan pertimbangan dalam menilai suatu karangan. Untuk mengukur kualitas cerita, hendaknya mencoba memberikan kepada orang lain untuk mengomentari, bagaimana kritik dan sarannya, apakah kelebihan dan kelemahannya diperbaiki lagi (Komaidi 2005: 182).

Penulisan cerpen dalam penelitian ini menggunakan model pembelajaran menulis pengandaian diri yang dapat digunakan untuk menulis cerpen. Pengandaian diri merupakan suatu gagasan yang muncul dari daya imajinasi yang membentuk suatu cerita tersendiri dan dalam cerita tersebut seolah-olah seseorang masuk dan menjadi pelaku utama atau tokoh peran utama dalam ceritanya. Pada model ini, terdapat tiga langkah, yaitu pengelompokan (clustering) (DePoter 2004:181), menulis (fast writing), dan memperagakan bukan memberitahukan (show not tell).

Penelitian teknik pengandaian diri dilakukan dengan asumsi bahwa penelitian ini relevan, terutama dalam pembelajaran menulis cerita pendek kurang diperhatikan. Penelitian terdahulu hanya mengkaji tentang kemampuan menulis cerpen yang dilakukan oleh Pramana Putra (2016) tanpa menggunakan metode atau teknik tertentu. Pramana Putra mengangkat penelitian dengan judul "Kemampuan Menulis Cerpen Siswa Kelas X1 SMA Negeri 1 Melaya Ditinjau dari Unsur Intrinsik. Hasil penelitian menunjukkan bahwa kemampuan siswa di dalam menulis cerpen sudah baik dengan perolehan nilai ratarata kelas 75,85 . Ini terbukti dari hasil analisis unsur intrinsik yang dilakukan oleh peneliti. Penyajian unsur-unsur intrinsik (tokoh, alur, sudut pandang, latar, tema, gaya bahasa, amanat) juga sudah baik dilakukan oleh siswa. Penelitian yang dilakukan oleh Pramana Putra (2016) memiliki persamaan dengan penelitian ini, yaitu mengkaji tentang menulis cerpen. Namun demikian, lebih banyak perbedaan terutama pada aspek subjek dan latar penelitian. Selain itu, penelitian ini menggunakan teknik pengandaian diri dalam pembelajaran, sedangkan penelitian terdahulu hanya meneliti kemampuan menulis cerpen tanpa menerapkan strategi tertentu. Oleh karena itu, penelitian ini dilakukan untuk memperkaya penelitian tentang pembelajaran menulis cerpen dengan menggunakan teknik pengandaian diri.

Penelitian ini bertujuan untuk mendeskripsikan efektivitas teknik pengandaian diri terhadap kemampuan menulis cerita pendek siswa kelas VII SMP Negeri 2 Baranti Kabupaten Sidenreng Rappang. Adapun tujuan jangka panjang yang diharapkan dari penelitian ini yaitu adanya pemilihan model pembelajaran terkini yang mampu menstimulus siswa dalam menulis cerpen.

\section{METODE}

Desain penelitian yang digunakan dalam penelitian ini adalah desain penelitian eksperimen. Penelitian ini merupakan penelitian eksperimen yang terdiri atas dua kelompok, yaitu kelompok eksperimen (kelompok yang menggunakan teknik pengandaian diri dalam menulis cerpen) dan kelompok kontrol (kelompok yang tidak menggunakan teknik pengandaian diri dalam menulis cerpen).

Penelitian ini dilaksanakan di kelas VII

SMP Negeri 2 Baranti tahun pelajaran 2016/ 2017. Pelaksanaan dilaksanakan selama empat (4) bulan, yakni Mei sampai Agustus 2017. Populasi dalam penelitian ini sebanyak 136 orang yang tersebar ke dalam tujuh kelas. Sifat dan karakteristik populasi penelitian ini adalah homogen karena penempatan siswa dalam suatu kelas tidak didasarkan pada tingkat prestasi belajar. Penarikan sampel dalam penelitian ini menggunakan teknik random kelas dan yang terpilih adalah kelas VIIf dengan jumlah 20 orang siswa.

Teknik pengumpulan data yang digunakan adalah teknik dokumentasi dan tes kemampuan menulis. Teknik dokumentasi digunakan untuk memperoleh data tentang prestasi awal siswa dalam pembelajaran cerpen. Adapun tes 
yang dilakukan untuk medapatkan gambaran tentang kemampuan siswa dalam menulis cerpen. Dalam pelaksanaannya, siswa ditugasi menulis cerpen dengan kompetensi dasar dalam Kurikulum 2013 kelas VII semester satu. Data yang terkumpul dianalisis dengan menggunakan teknik statistik inferensial jenis uji t.

\section{HASIL DAN PEMBAHASAN}

\section{Kemampuan Sis wa Kelas VII SMP Negeri 2 Baranti Menulis Cerpen}

Pada bagian ini akan disajikan data tentang hasil tes kemampuan siswa kelas VII SMP Negeri 2 Baranti dalam mata pelajaran Bahasa Indonesia, baik yang berada pada kelompok eksperimen maupun kelompok kontrol.

\section{Kelas Eksperimen}

Berdasarkan hasil analisis data dengan 10 orang siswa, tidak ada siswa yang mampu memeroleh nilai 100 sebagai nilai maksimal. Nilai tertinggi yang dicapai oleh siswa adalah 90 yang dicapai oleh 1 orang (10\%) dan nilai terendah yang diperoleh oleh siswa adalah 60 yang dicapai oleh 1 siswa (10\%). Selanjutnya, sampel yang mendapat nilai 65 berjumlah 3 orang (30\%); sampel yang mendapat nilai 70 berjumlah 3 orang (30\%); sampel yang mendapat nilai 80 berjumlah 2 orang (20\%).

Tabel 1. Distribusi Nilai Kemampuan Kelompok Eksprimen

\begin{tabular}{cccc}
\hline No. & Nilai & Frekuensi & Persentasi \\
\hline 1 & 60 & 1 & $10 \%$ \\
\hline 2 & 65 & 3 & $30 \%$ \\
\hline 3 & 70 & 3 & $30 \%$ \\
\hline 4 & 80 & 2 & $20 \%$ \\
\hline 5 & 90 & 1 & $10 \%$ \\
\hline
\end{tabular}

Berdasarkan hasil analisis deskriptif tersebut diperoleh rangkuman nilai kemampuan menulis cerpen siswa kelas VII SMP Negeri 2 Baranti dengan menerapkan teknik pengandaian diri Untuk lebih jelasnya, rangkuman karakteristik distribusi nilai yang diperoleh siswa ditunjukkan pada tabel 1 . Nilai siswa tersebut dapat dikonversikan ke dalam klasifikasi ketuntasan kemampuan menulis cerpen dengan menerapkan teknik pengandaian diri, yaitu sampel yang memeroleh nilai 65 ke atas berjumlah 9 siswa (90\%) dan tidak hanya 1 siswa sampel yang memeroleh nilai di bawah 65 (10\%). Dengan demikian, dapat dikatakan bahwa keriteria ketuntasan kemampuan menulis cerpen dengan menerapkan teknik pengandaian diri kelas eksperimen memadai. Hal ini dibuktikan dari nilai yang diperoleh siswa sampel yang memeroleh nilai 65 ke atas mencapai kriteria tingkat kemampuan siswa sampel, yaitu $85 \%$.

\section{Kelas Kotrol}

Berdasarkan hasil analisis data sebanyak 10 orang siswa yang dianalisis diperoleh gambaran, yaitu tidak ada siswa yang mampu memeroleh nilai 100 sebagai nilai maksimal. Nilai tertinggi yang dicapai oleh siswa adalah 60 yang dicapai oleh 2 orang (20\%) dan nilai terendah yang diperoleh siswa adalah 45 yang dicapai oleh 3 siswa (30\%). Selanjutnya, sampel yang mendapat nilai 50 berjumlah 2 orang (20\%); sampel yang mendapat nilai 55 berjumlah 3 orang $(30 \%)$. Berdasarkan hasil analisis deskriptif tersebut diperoleh rangkuman nilai kemampuan menulis cerpen siswa tanpa menerapkan teknik pengandaian diri pada berbagai karakteristik distribusi nilai. Untuk lebih jelasnya, rangkuman karakteristik distribusi nilai yang diperoleh siswa ditunjukkan pada Tabel 2.

Tabel 2. Distribusi Nilai Kemampuan Menulis Cerpen Kelas Kontrol

\begin{tabular}{cccc}
\hline No. & Nilai & Frekuensi & Persentasi \\
\hline 1 & 45 & 3 & $30 \%$ \\
\hline 2 & 50 & 2 & $20 \%$ \\
\hline 3 & 55 & 3 & $30 \%$ \\
\hline 4 & 60 & 2 & $20 \%$ \\
\hline
\end{tabular}

Berdasarkan Tabel 2, dapat diketahui bahwa di antara 10 siswa yang dites, nilai tertinggi yang diperoleh siswa adalah 60. Selanjutnya, nilai terendah yang diperoleh siswa adalah 45 . Nilai siswa tersebut dapat dikonversikan ke dalam klasifikasi ketuntasan kemampuan menulis cerpen siswa tanpa menerapkan teknik pengandaian diri, yaitu tidak ada sampel (0\%) yang memeroleh nilai 65 ke atas, sedangkan siswa sampel yang memeroleh nilai di bawah 65 berjumlah 10 siswa (100\%). Dengan demikian, 
Tabel 3. Mean Kelompok Eksperimen dan Kelompok Kontrol

\begin{tabular}{|c|c|c|c|c|c|c|}
\hline $\mathrm{F}(\mathrm{x} 2)$ & fx & $\mathrm{f}$ & $\mathrm{N}(\mathrm{X}, \mathrm{Y})$ & $\mathrm{f}$ & fy & $\mathrm{f}(\mathrm{y} 2)$ \\
\hline 8100 & 90 & 1 & 90 & 0 & 0 & 0 \\
\hline 12800 & 160 & 2 & 80 & 0 & 0 & 0 \\
\hline 14700 & 210 & 3 & 70 & 0 & 0 & 0 \\
\hline 12675 & 195 & 3 & 65 & 0 & 0 & 0 \\
\hline 3600 & 60 & 1 & 60 & 2 & 120 & 7200 \\
\hline 0 & 0 & 0 & 55 & 3 & 165 & 9075 \\
\hline 0 & 0 & 0 & 50 & 2 & 100 & 5000 \\
\hline 0 & 0 & 0 & 45 & 3 & 135 & 6075 \\
\hline 51875 & 715 & 10 & & 10 & 520 & 27350 \\
\hline
\end{tabular}

dapat dikatakan bahwa ketuntasan kemampuan menulis cerpen tanpa menerapkan teknik pengandaian diri kelas kontrol belum memadai. Hal ini dibuktikan dari nilai yang diperoleh sisa sampel yang memeroleh nilai $65 \mathrm{ke}$ atas tidak mencapai kriteria, yaitu $85 \%$. Perolehan nilai siswa terse-but tidak mencapai ketuntasan yang ditetapkan, yakni $85 \%$ siswa yang harus mendapat nilai 65 ke atas.

\section{Keefektifan Teknik Pengandaian Diri dalam Menulis Cerpen}

Keefektifan teknik pengandaian diri dalam pembelajaran menulis cerpen tersebut diukur berdasarkan perolehan nilai kelas eksperimen dan kelas kontrol. Selanjutnya, berdasarkan perolehan nilai kelas eksperimen dan kelas kontrol dilakukan analisis statistik deskriptif uji t. Hasil analisis data menunjukkan bahwa nilai empiris yang diperoleh dalam derajat bebas (18), pada taraf signifikansi $1 \%$ diperoleh 2,878 dan taraf signifikansi 5\% diperoleh 2,101. Nilai empiris (analisis data) lebih besar dari pada nilai tabel (nilai teriotis), yakni 5,53>2,878 (1\%) dan $5,53>2,101(5 \%)$. Berdasarkan hasil tersebut, maka dapat disimpulkan bahwa hipotesis diterima, sehingga ada perbedaan yang signifikan antara kelas yang menggunakan teknik pengandaian diri dengan tanpa menggunakan teknik pengandaian diri. Dengan demikian, teknik pengandaian diri efektif diterapkan dalam pembelajaran menulis cerpen.

\section{Pembahas an}

Pembahasan hasil penelitian ini mencakup kemampuan siswa dan keefektifan teknik pengandaian diri.

\section{Kemampuan Menulis Cerpen dengan Teknik Pengandaian Diri}

Dalam pembelajaran menulis cerpen bagi kelas yang tidak menerapkan teknik pengandaian diri, yaitu siswa mengalami kendala dan hambatan. Rata-rata siswa kesulitan dalam menuangkan ide dan merangkaian menjadi sebuah karangan. Mereka sulit menulis cerpen karena guru hanya langsung menugasi siswa menulis tanpa menggunakan teknik pengandaian diri. Aktivitas dan kegiatan siswa pada siswa yang tidak menerapkan teknik pengandaian diri menunjukkan bahwa semangat dan perhatian siswa dalam pembelajaran masih kurang. Hal ini tampak dari kurangnya perhatian serius dari siswa dalam menanggapi materi. Sikap siswa pada umumnya masih kurang dalam memberikan tanggapan terhadap teknik yang disajikan.

Pada saat pembelajaran berlangsung, hanya sebagian kecil siswa yang benar-benar aktif. Selain itu, ditemukan adanya siswa yang melakukan aktivitas yang tidak ada hubungannya dengan pelajaran seperti berbincang-bincang dengan sesama teman. Hal ini menunjukkan bahwa siswa kurang memiliki motivasi dan ketertarikan untuk belajar. Fenomena yang dialami oleh siswa dalam menulis cerpen tersebut berdampak pada evaluasi hasil belajar. Dapat diketahui bahwa frekuensi dan persentase kemampuan siswa menulis cerpen, yaitu tidak ada siswa $(0 \%)$ yang mendapat nilai $65 \mathrm{ke}$ atas. Berdasarkan data tersebut, dapat dinyatakan bahwa kemampuan menulis cerpen siswa kelas kontrol (tanpa menerapkan teknikpengandaian diri) belum memadai. Berbeda dengan fenomena yang terjadi dalam pembelajaran menulis cerpen siswa dengan menerapkan teknik pengandaian diri. Tampak sebagian besar siswa seolah tidak menulis cerpen. Jika ada siswa yang mengalami kesulitan dalam 
menuangkan ide dan mengorganisasikannya menjadi karangan, maka siswa diarahkan untuk menggali pengalaman menarik yang pernah dia alami dan mengurutkan bagian demi bagian dan merangkainya menjadi sebuah karangan. Hal tersebut berdampak positif pada nilai yang diperoleh siswa dalam menulis cerpen. Dapat dinyatakan bahwa tingkat kemampuan menulis cerpen siswa dengan menerapkan teknik pengandaian diri dikategorikan tinggi. Hal ini dibuktikan dari nilai yang diperoleh siswa sampel yang memeroleh nilai 65 ke atas mencapai kriteria tingkat kemampuan siswa sampel, yaitu $85 \%$. Masalah yang terjadi pada kelas kontrol yang berpengaruh pada rendahnya kemampuan siswa menulis cerpen sebagaimana dipaparkan sebelumnya dapat diselesaikan dengan menerapkan teknik pengandaian diri.

\section{Keefektifan Teknik Pengandaian Diri dalam Menulis Cerpen}

Pembelajaran menulis pengandaian diri yang digunakan untuk menulis cerpen melalui tiga langkah, yaitu pengelompokan (clustering), menulis (fast writing), dan memperagakan bukan memberitahukan (show not tell).

Pengelompokan (clustering). Pengelompokan yang dikembangkan oleh Gabriele Rico adalah suatu cara memilih permikiran-pemikiran yang saling berkaitan dan menuangkannya di atas kertas secepatnya, tanpa mempertimbangkan kebenaran atau nilainya. Suatu pengelompokan yang terbentuk di atas kertas hampir seperti proses berpikir yang terjadi dalam otak, walaupun dalam bentuk yang sangat disederhanakan (DepPoter 2004:181).

Keuntungan dari teknik pengelompokan menurut Hernowo, yaitu (1) membuat peserta didik mampu melihat dan membuat hubunganhubungan antar gagasan; (2) membantu siswa mengembangkan gagasan-gagasan yang telah dikemukakan; dan (3) membuat siswa dapat menulusuri jalur yang dilalui otak hingga tiba pada suatu konsep tertentu.

Menulis cepat (fast writing). Menulis cepat membantu siswa untuk menghindari penghentian ide-ide. Menulis cepat sebuah teknik untuk menulis cerpen agar tulisan yang ada dalam pikiran dapat mengalir bebas tanpa hambatan. Siswa menulis berdasarkan kata-kata yang telah dikelompokan tadi. Siswa menulis cerpen dengan cepat tanpa memperhatikan kesalahan-kesalahannya. Karena jika siswa mem- perhatikan kesalahannya maka akan menghentikan kreatifitasnya.

Memperagakan bukan memberitahukan (show not tell). Pada teknik ini, siswa menulis draf kasar tentang cerpennya. Cerpen yang masih berupa draf kasar ini, kemudian dipoles agar menjadi cerpen yang bahasanya menjadi hidup. Memperagakan bukan memberitahukan artinya memberikan penjelasan secara terperinci seperti apa tampaknya, rasanya, dan kedengarannya.

Berdasarkan hasil analisis data, tes kemampuan menulis cerpen dapat disimpulkan bahwa teknik pengandaian diri cocok digunakan. Hal ini dinyatakan berdasarkan hasil penelitian yang menunjukkan bahwa kemampuan siswa menulis cerpen meningkat. Pernyataan tersebut didukung dan diperkuat berdasarkan hasil perhitungan tes. Perbandingan hasil kemampuan kelas kontrol dan eksperimen menunjukkan bahwa nilai $t$ hitung > nilai $t$ tabel. Hal ini menunjukkan bahwa hipotesis penelitian yang diajukan diterima. Hasil kemampuan menulis cerpen siswa kelas kontrol dan eksperimen tampak jelas berdasarkan perbandingan dalam Tabel 3 .

Teknik pengandaian diri dapat membantu mengorganisasi ide dengan baik dan menuangkannya menjadi sebuah cerpen. Hal ini dinyatakan karena saat pembelajaran berlangsung siswa bersemangat mengungkapkan pengalaman menarik mereka dan mengurutkannya menjadi bagian kejadian lalu merangkainya menjadi sebuah cerpen.

Berdasarkan uraian tersebut dapat disimpulkan bahwa teknik pengandaian diri efektif digunakan. Hal ini dinyatakan berdasarkan hasil penelitian yang menunjukkan bahwa kemampuan siswa menulis cerpen meningkat. Pernyataan tersebut didukung dan diperkuat berdasarkan hasil perhitungan tes. Perbandingan hasil kemampuan pretes dan postes menunjukkan bahwa nilai $\mathrm{t}$ hitung > nilai t tabel. Hal ini menunjukkan bahwa hipotesis penelitian yang diajukan diterima.

Peran teknik pengandaian diri dalam pembelajaran, khususnya menulis cerpen sejalan uraian sebelumnya bahwa teknik pengandaian diri yang dilakukan melalui tiga tahap yaitu (1) pengelompokan; (2) menulis cepat, dan (3) meragakan bukan memberitahukan.

Agar pembelajaran lebih terarah, maka dapat digunakan teknik pengadaian diri. Teknik ini dapat membantu siswa mengeluarkan ide-ide ke dalam tulisan dan mengembangkannya menjadi cerpen. Pada dasarnya, penerapan model pembelajaran menulis pengandaian diri akan 
mempermudah siswa di dalam menulis cerpen sehingga kemampuan menulis cerpen akan meningkatkan dan siswa tidak beranggapan bahwa menulis cerpen itu hal yang susah dan pembelajaran menulis cerpen adalah hal yang membosankan.

\section{PENUTUP}

Berdasarkan hasil analisis data ditemukan bahwa hasil pembelajaran menulis cerpen siswa dengan menerapkan teknik pengandaian diri dikategorikan tinggi dan telah mencapai ketuntasan belajar. Hal ini dinyatakan karena nilai yang diperoleh siswa mencapai kriteria yang ditetapkan, yaitu mencapai $90 \%$ atau sebanyak 9 siswa yang mendapat nilai 65 ke atas. Hal tersebut bermakna bahwa teknik pengandaian diri efektif dalam meningkatkan kemampuan menulis cerpen siswa. Berbeda dengan pencapaian tersebut, hasil pembelajaran menulis cerpen

\section{DAFTAR PUSTAKA}

Aminuddin. 2010. Pengantar Apresiasi Karya Sastra. Bandung: Sinar Baru Algensino.

DePoter, Bobbi. 2009. Quantum Writer: Menulis dengan Mudah, Fun, dan Hasil Memuaskan. Bandung: Kaifa.

Laksana, Puja. 2009. Panduan Praktis Mengarang Menulis. Semarang: Aneka Ilmu.

Hernowo. 2003. Quantum Writing: Cara Cepat nan Bermanfaat untuk Merangsang Munculnya Potensi Menulis. Bandung: Mizan Learning Center.

Komaidi, Didik. 2006. Aku Bisa Menulis. Jakarta: Sabda. siswa tanpa mene-rapkan teknik pengandaian diri dikategorikan sa-ngat rendah dan belum mencapai ketuntasan be-lajar karena nilai yang diperoleh siswa belum mencapai kriteria yang ditetapkan, yaitu tidak ada (0\%) yang memeroleh nilai 65 ke atas. Teknik pengandaian diri efektif diterapkan da-lam pembelajaran menulis cerpen.

Perbandingan hasil kemampuan kelas eksperimen dan kelas kontrol menunjukkan bahwa nilai t hitung > nilai t tabel. Hal ini menunjukkan bahwa hipotesis penelitian yang diajukan diterima.

Berdasarkan hasil penelitian, guru bahasa Indonesia disarankan menggunakan teknik ini dalam pembelajaran menulis cerpen. Teknik pengandaian diri dapat meningkatkan kemampuan siswa dalam menuangkan ide dan merangkainya menjadi sebuah cerpen. Teknik pengandaian diri juga layak diujicobakan pada aspek pembelajaran sastra lainnya.

Nugroho, Hamdan. 2009. Pembelajaran Menulis Cerpen.(online).http://Hams mars.blodspot.c om/2009/06/pembelajaran-menulis -cerpendengan-html Diakses: 17 Juni 2013.

Nurgiyantoro, Burhan. 2002. Teori Pengkajian Fiksi. Yogyakarta: Gajah Mada University Press.

Pramana Putra, Dedy. Kemampuan Menulis Cerpen Siswa Kelas X 1 SMA Negeri 1 Melaya Ditinjau dari Unsur Intrinsik. (online).https://ejournal.undiksha.ac.id/ index.php/JJPBS/article/view/1181, diakses 20 Desember 2017. 